\title{
SOME THOUGHTS on HISTORY TEACHING
}

\author{
Kubilay YAZICI
}

Niğde Ömer Halisdemir Üniversitesi, Eğitim Fakültesi, E-posta: kyazici@ ohu.edu.tr

orcid.org/ 0000-0002-6057-8192

Article Info

\begin{tabular}{c|l} 
Article Type & Research \& Theoretical \\
Received & 11.03 .2019 \\
Accepted & 04.05 .2019 \\
DOI & $10.17497 /$ tuhed.538198 \\
Corresponding & Kubilay YAZICI \\
Author & $\begin{array}{l}\text { Yazic1, K. (2019). Some thoughts on history teaching. Turkish } \\
\text { Cistory Education Journal, 8(1), ss. 82-97. doi: } \\
10.17497 / \text { tuhed.538198 }\end{array}$
\end{tabular}



Öz: İçinde yaşadığımız yüzyılda yaşanan hızlı değişim ve gelişim, etkisini her alanda olduğu gibi eğitim-öğretim alanında da hissettirmektedir. Bu süreçte öğretim programlarının içerikleri çağın gerektirdiği düşünülen farklı içerik ve uygulamalarla donatılmaktadır. Geçmişten günümüze eğitimöğretim sistemlerinin vazgeçilmezleri arasında var olan tarih dersleri ise yaşanan bu değişim ve dönüşümden yeterince etkilenmemiş görünmektedir. Kaleme alınan bu çalışmada çeşitli örneklerle dile getirilmeye çalışıldığı üzere tarih öğretiminin dönüşümü sağlayamamış olmasının farklı gerekçeleri olduğu görülmektedir. Bu çalışmada tarih öğretimi alanında olması gerektiği düşünülen bazı uygulamaların, öğrenme-öğretme sürecinde yer almaları durumunda nasıl bir yarar sağlayacakları ekseninde tartışııması yoluna gidilmiştir. Bu bağlamda çeşitli içerikteki uygulamalar, alt konu başlıkları şeklinde oluşturularak okuyucunun aklında var olabilecek soru işaretlerinin bir kısmının giderilmesi amaçlanmıştır. Yapılan öneriler tarih öğretimiyle ilgili yaşanan sorunlara farklı bir bakış açısıyla çözüm önerileri getirilebilir mi mantığı doğrultusunda dile getirilmişlerdir.

Anahtar Kelimeler: Tarih, Tarih Eğitimi, Öğretim Problemleri

Abstract: The rapid change and transformation we experience in this century makes its effect evident on the field of education as in every field. In this process, the contents of curriculums are provided with various contents and applications thought to be the necessities of the time. However, history lessons, which have been among the essential parts of educational systems from past to present, seem not to be affected enough by these changes and transformations. It is seen in this study that, as stated through various examples, there are different reasons for the fact that history education has been unable to realize its transformation. In the study, some practices which are thought to be necessary in history education were discussed in terms of their possible benefits in the event that they exist in the learning-teaching process. In this context, it is aimed to answer possible questions in the readers' minds by drawing up some practices with various contents under sub-titles. The suggestions made in the study were prepared in line with the purpose to offer solutions to the problems about history education from different points of view.

Keywords: History, History Education, Teaching Problems

\section{Introduction}

Every state that has expired or still exists on earth considered the teaching of history to young generations as an indispensable teaching area for reasons such as the transfer of citizenship, the education of the administrators and the teaching of old languages (Safran, 2006). At this stage, the political power that holds the absolute power of the state plays a decisive role in which subjects should be included in the curriculum. Sometimes, the regime of the state or the characteristics of the human model that political power wants to cultivate (Dönmez and Yazıcl, 2013) as well as the issues that include solutions or measures for the 
problems that the state is facing or will face are effective in determining the content of the subjects in history education.

In this study, it is aimed to provide a critical point of view to the subjects which are mostly ignored or not put into practice in the teaching of history subjects. In this context, subheadings of the topics mentioned were explained with examples and discussed. Recommendations do not include required applications. The logic of the study is based on the idea of giving an explanation about why these practices are not included and what kind of history teaching can be given if they are included, and structured within the following topics.

\section{Choice of Subject}

Most of the curriculums in our country are structured in a spiral form with the contents of the courses before and after them. In this way, it is planned to enable students to obtain the information they need to acquire more comprehensively and in greater detail. Social studies lessons can be given as examples of the lessons that are formed in this way. As for history lessons, the issue that mostly goes unnoticed is that the contents frequently repeat as the education level changes; e.g. Turkish Rebuplic History of Reforms and Kemalism Course Curriculum (MEB, 2017a; MEB, 2017b). This situation is expressed even by high-school graduates (Mutluer, 2014). Therefore, it can be argued that the existence of a roofing program that includes all educational levels from primary to high school will be useful for eliminating these problems. In this way, the concepts, skills and values required for the students to learn the history subjects from the beginning of primary school to the last year of high school can be structured in a more systematic way.

Another most important problem experienced during the teaching of history subjects is the choice of subject (Ulusoy, 2011). The events of our history are as old as the history of mankind and we undertake roles in many events, institutions or organizations that are effective not only on our own history but also on the shaping of human history. This may bring about the idea that "all the subjects included in the textbooks must exist in history teaching". However, the most important issue that needs to be discussed and decided on is whether these issues continue to exist in the curriculum or teaching them is more important. If a common starting point is needed, it is important that the teaching of the subjects that are considered essential for students to learn be structured considering the students' learning situations. At this stage, it can be argued that it would be beneficial to prepare the contents 
that are not among the essential subjects in the form of elective subject so that the students are allowed to learn what they want to learn.

It is thought that it will be beneficial to prepare history textbooks with the same logic underlying the privately published history notebooks which are frequently used by students who are studying for transition examination from primary to secondary education and public personnel selection examination. Such an approach will enable both the inclusion of the subjects that are considered essential for students to learn in the textbooks and the use of blank pages of the textbooks by students as an environment where students are given the opportunity to learn the subjects they are interested in personally. In this way, students will be able to systematically address the topics they choose just like historians and develop skills such as writing and decision-making that are frequently mentioned within the skills in the curriculum.

It is a controversial situation how effectively learners, who constitute one of the important dimensions of learning, will learn a subject in which they are not interested. However, no detailed study has been carried out about which history subjects students are interested in enough to influence the curricula. The studies on the subject in the literature have remained limited (Kaya and Demirel, 2008; Ulusoy, 2009). To explain the issue through a sample application; after explaining the basic stages of the history of Turkish civilization, students who are interested in sports, literature and architecture should go through a process of sports, literature and architecture education respectively. In this way, both the information that can not be remembered will be prevented and the learning process will be easily realized by taking into account the constructivist principles.

\section{The History of Winners}

When the sub-headline above is taken into consideration, the following question may arise: The losers have already lost; what place could they have in history education? Indeed, it is seen that the views and philosophies of the losers are not sufficiently involved in history textbooks. Examining the history textbooks in terms of the existence of historical characters justifies this claim (Dönmez and Yazıcl, 2013). The reasons underlying success or achievement are presented only from the winners' viewpoints and the effects of other events or individuals 
that influence historical events are presented to the students without being adequately studied.

As Stradling (2003: 128-129) stated in this stage, it is not always possible to determine different perspectives on a particular subject or development by looking at the content of a text. Therefore, in the selection of the figures who have important roles in the events that changed the flow of history, it is considered appropriate to mention not only the ideas, opinions and behaviours of the winners but also those of the losers in textbooks, which can be regarded as the embodiments of instructional programs. Referring to the life stories of the losers in the curriculum can enable students to understand better the effects of the conditions of the period on the behavior patterns of historical characters from the beginnig to the end of the events. In this sense, the projects and assignments are expected to help students learn the life stories of the losers and understand why and how they approached the events.

\section{Historical Figure, Historical Character or Historical Person?}

It is a reality that all the characters included in the history textbooks have a historical personality (Dönmez and Yazıcı, 2013). But at this stage, the following question comes to mind; 'Are the effects of the characters on the historical events at the same level?'. For example; are the roles of 'Seyit Onbaşı' and 'Niğdeli Ali' in the Gallipoli battle equally important? The answer is certainly "No". In this context, a historical figure may be referred to as any person who lived in the past and had an impact on the realization of an event or thought that has exceeded the centuries. Such figures should include people who are the founders of thought systems, belief systems and states or who have played an important role in shaping a state. When it comes to the concept of historical character, it should be considered as a person who has a primary effect on a historical event that directly or indirectly affect masses of people. A historical person can be described as a person who influences historical figures and characters while they realize an event or express their opinions. For this reason, the characters included in the textbooks should be classified from the most effective to less effective as Historical Figure, Historical Character and Historical Person respectively.

Such a classification makes it possible to discuss in detail the impact of the human factor on events or thoughts. Otherwise, it may lead to misunderstandings in deciding who has more influence on the occurrence of the event, understanding the nature of the impact and evaluating the results of the event. This sort of classification will ensure that historical 
figures, historical characters and historical people are addressed in a correct and balanced context in history textbooks, in which the authors are given initiative to decide which historical figures, characters or people to mention (see Dönmez and Yazıcl, 2013). To set an example for this initiative, some of the founders of the Democratic Party were mentioned in the textbooks published by the Ministry of National Education while they were not included in the coursebooks published by private publishers (Dönmez and Yazıcl, 2013). It should be keep in mind that such situations can repeat in the future as well, which may cause inequalities in both the instruction of subjects and examinations.

\section{The Use of Memoirs}

One of the most important reasons why history courses are seen as boring lessons is that these courses are written as a series of political events (Köse and Yıldız, 2012). Indeed, it is seen as a distant possibility to expect students to structure the dates of successive events and the constituents of agreements in a context at the desired level. Currently, course subjects are often memorized by students (Ulusoy, 2011; Kabapınar, 2009, Kaya \& Güven; 2012) and such memorized knowledge is forgotten soon after the exams. Therefore, we claim that memoirs will serve a significant function in preventing history courses from being just a state of political events. When the literature is examined, it is seen that the studies on this issue are limited (For example, see Altıkulaç and Gökkaya, 2014; First, 1998; Dönmez, Yazıcı and Uslu, 2016).

Although some teachers of history courses have reservations on the issue, memories can be used as a teaching tool (Dönmez, Yazıcı and Uslu, 2016). It is believed that structuring the contents of the memoirs on humane events rather than political events, or describing the events from the viewpoints of the people who lived at the time by considering their moods such as love, anger, happiness, pain, ambition, etc., will contribute to increase the memorability of the knowledge.

In articles written by Hanilçe (2008) in Turkey, it is stated that 235 memoirs were published between 1908 and 1922 while in another work written by Akter (1999-2000) it is indicated that there are more than 400 memories between 1918-1938 (See Dönmez, Yazıcı and Uslu, 2015). Some memoirs included within the numbers mentioned by the two researchers may in fact be the same memoirs. However, it can still be assumed that many 
memoirs were published between 1908 and 1938. When these numbers are taken into consideration, it will be better understood that we are deprived of a great source of literature in the education process.

At this stage, it can be stated that memories are a unique source in the understanding of the life stories of the losers / failers who are dealt with in a separate subheading in the study. However, the effect of the emotional state of the author on the content of the memoirs makes it necessary for them to be examined carefully before they are used in the education process. Because of this reason stated by Özen (2017), memoirs are often treated as literary texts rather than as a historical document. Therefore, it should be paid attention to whether the expressions in the contents result from truelife events or those that are likely to happen, and whether the expressions are exaggerated or not. The simplification of the knowledge given in the memoirs without any disturbance following a careful examination by a commission of experts is believed to contribute to a better understanding of the contents and to the minimization of the problems that may arise from the use of memories.

\section{Chance or Fate Factor}

Chance and fate are two related concepts. Chance in the Current Turkish Dictionary on the official website of the Turkish Language Institution refers to 'the reason of some incidents that cannot be explained by logic: power, baht, fortune, felek', 'the likelihood of an event' and 'a favorable situation that a person obtains by chance rather than by knowledge and labor'. On the other hand, fate is defined as 'destiny' and 'usually inevitable bad fortune' (TDK, 2017).

It is believed that it would be useful to make some explanations before going into these two concepts and their importance in history teaching. The concept of fate has a meaning in belief systems while luck is a concept that is generally used in order to explain events that are less likely to occur. Fate is the result of a series of events. However, chance emerges as a factor which has a striking quality makes an event happen. In this sense, it should not be ignored that chance can be handled within the concept of fate. In line with these explanations, the reasons for the lack of fatalism in the teaching of history in particular can be found understandable. However, there is no clear information in the literature about whether the effects of unordinary events in shaping fate on the course of history should be included in history education and, if so, how to deal with them. 
At this stage, the effect of chance encountered in many historical events on the course of history is dealt with little if any both in the instructional programs and in the teaching process. For example, if Seyit Corporal hadn't held the 360-kg ball Shell, launched it and sunk the Queen Elizabeth battleship, how would the Gallipoli War have ended? Or, if Queen Cleopatra hadn't been so beautiful in ancient Egypt (Lilletun, 2013) and if she hadn't been loved by Caesar, would the Egyptian and Roman history have developed in the way as we were taught? The first of the examples given is important in terms of understanding the effect of chance in the formation of history indirectly while the second is important in understanding the effect of fate and it should be considered in depth.

It can be claimed that the most important dilemma faced by history educators about this issue results from the concern that students may overemphasize the chance factor in the realization of a historical event while they attribute too much importance to the concept of fate from a broad perspective. So, the probability that chance or fate can prevent man's effort will also lead to the loss of lesson-taking function which is the main purpose of history teaching. It is a controversial issue how acquiring such information, which is avoided in educational programs, through non-formal means will affect the main objectives of the curriculum. At this stage, mentioning the chance factor especially at high school level will be useful for understanding that human endeavour may not be effective in the realization of a historical event in certain cases.

\section{The Problem of Currentness}

It can be claimed that one of the problems frequently mentioned in our system of education is the lack of relationship between the information learned and the current life. In this context, while the use of current events in pre-school (Oktay and Unutkan Polat, 2005) and social studies (Deveci, 2007; Gedik, 2010, Memişoğlu \& Güçin, 2017) classes is frequently recommended in the literature, such events are not included in history classes, whose subject is past events, because of the concern that the principle of objectivity will be damaged. Although recent history courses contain topics that concern recent history, there is still no consensus on the need for such an application. At this stage, the transfer of recent events in history courses is often neglected due to the reasons underlying the fact that even a historian wants a generation to pass after the event. 
The questions that come to mind are 'What is the purpose of history teaching?' and 'Is the main purpose of history teaching to learn from past events or to ensure that students are provided with citizenship qualifications?' Surely, both are included in the purpose of history teaching (Aslan, 2006; Demircioğlu, 2006). However, a decision on this issue should not lead to the omission or neglect of the other.

The fact that one of the objectives of the teaching can be expressed as increasing the citizenship qualifications may suggest that it is a good practice to consider the recent history, or the events whose effects are much felt nowadays, in history classes. However, what should be done in practice is to try to give the past connections of the events that take place today and to evaluate current events as the outcomes of past events. In this way, it may be possible to enable students to more easily understand the fact that past is not only past but it may also shape the future. Such a practice can be given to students in the form of job and project tasks, as indicated by Dönmez and Tangülü (2012).

\section{Use of Map as Material}

It is accepted that the use of materials in history courses will contribute to both understanding of the current situation and reinforcement of knowledge, and many educators point out in their studies the benefits of education with appropriate materials (Öztürk, 2002; Demircioğlu, 2014; Kuzgun and Gospel, 2016). However, it is seen that there still exist some shortcomings during the use of materials in history teaching (Şengül Bircan and Safran, 2013) and various mistakes are made. We claim that the unflexible, or disposable, natures of these materials are among the main reasons of these problems. This leads to a limited contribution of materials to explaining the relationship between the causes and results of historical events as a process. To give an example, the lands owned by the Ottoman Empire in the administration of a sultan are shown on one map while those of another sultan ruled after him are shown on a different map. However, it would be better understood by the students how the changes in the boundaries of the previous and subsequent sultans took place especially if they were presented on maps of different formats or on the same map with different coloring.

Another mistake encountered within this issue is that the maps used in both primary school and high school education are of the same features. However, students' readiness levels are taken into account in the transfer of subjects even on textual basis while students' 
prior knowledge levels are not taken into consideration in map preparation process. For example, the map used in the teaching of history subjects in the 6th grade Social Studies course can also be used in the 12th Grade Revolution History and Kemalism course without any changes, which brings about the question 'Are classes, student levels, and subject contents not taken into account when designing maps?' (For detailed information, see Yazıcı and Özdemir, 2016). This indicates that the 'readiness' and 'subject matter suitability' principles of material use are ignored.

\section{Historical Emphaty}

It is stated that students should use their historical empathy skills to save history courses from having only the knowledge transfering nature (Yılmaz \& Koca, 2012). Considering the teaching objectives of history courses, it is certain that the importance of using historical empathy in learning-teaching process will be better understood. However, in our opinion, the application of empathy skills to the events and individuals within the content of history courses does not justify the evaluation of it within historical empathy.

While empathy can be applied to people living in the same period of time, the content of historical emphaty differs considering the people it is applied. A possible explanation for this is that people who still live or lived in the past may have different ways of thinking. However, the most important point that should not be overlooked at this stage is the effect of the characteristics of the period on the way people think. In fact, Yılmaz and Koca (2012: 859) explained the most important point to be considered in historical empathy with this statement; "It must not be forgotten that historical history is not to try to describe how we perceive or feel about the conditions of the people who lived in the past but to describe how they perceived their conditions". However, it is seen that question-based mistakes are still being made during the practice of historical empathy in the history courses. For example, students are still tried to be provided with historical empathy with questions such as if you were Mustafa Kemal Ataturk' or 'if you were Fatih Sultan Mehmet' (For more information see Yılmaz \& Koca, 2012).

The main purpose of historical empathy is to try to understand the emotions and thoughts of the actors of past events that caused them to do the actions. If we deepen the discussion through a sample, though not within the content of historical empathy, how a 
student who says 'I wouldn’t try to conquere İstanbul if I were Sultan Mehmet II' should be reacted? Which teacher can give a definite answer to this question? Even at this stage, students must be made to realize that not the feelings of the actors of past events but the past events themselves affect peoples' feelings and opinions, and that this effect may change from person to person. Unfortunately, it seems that the purpose of historical empathy is to make students adopt the reasons of the events caused by other events with expected outcomes rather than to make them understand the effects of the features of the time on peoples' behaviour patterns.

\section{Conclusion}

As a result of this study, it is considered pertinent to accept that criticism is an easy approach. It was stated at the beginning of the study that the criticisms and suggestions made in this study are not compulsory practices. However, it is frequently stated in academic environments that studies particularly in the field of history education should not focus on the same issues repeatedly and that they should be planned in a way that will enable teachinglearning process to be re-structured. For example, it is claimed that the use of materials will increase academic achievement, teachers have deficiencies in terms of using materials and subjects do not attract students' attention. In other words, the studies are often limited to determining current situation and the recommendations are often expressed with rambling and cliched statement such as 'in-service training should be given', 'use of material should be increased' and 'contents should be changed'.

One of the problems encountered at this stage can be expressed as the fact that the publications in the field of history teaching are read and taken into consideration only by academicians. In fact, the studies usually occupy only the library shelves or computer memories. Studies are mostly carried out on the basis of national education and undergraduate level in terms of contents. However; though a tranformation in instructional programs is expected on the basis of the results of these studies, it is obvious that there is no response to this expectation in practice. Therefore, it is thought that the examination of the 
contents of the publications particularly by the related institutions and organizations may help the deficiencies of our education system be eliminated and enable the system to improve.

While some of the problems experienced in the field of history education are universal, some should be handled within our education system but this fact often goes unnoticed. However, the selection of the contents of history courses is a national approach and the outcome of that approach. Although it is known that decision-making authorities are the main determinants of these contents, it is considered beneficial to take the opinions of the stakeholders for overcoming the deficiencies. The opinions mentioned are not those stated in the national education councils or the ones that do not shed light to the streotyped problems of our education system.

An obvious but inevitable problem within the current system is that the academic publications that are the main criterion of academic progress are mostly limited to determining current situation in terms of their contents rather than bringing a new perspective to the problems. In particular, it should not be forgotten that paying attention to originality while assessing the publications will both contribute to the improvement of history education in our country and enable the philosophy of history education to gain meaning again.

The purpose of history education is not to make young generations memorize the past. So, it can be claimed that the history teacher candidates should be given such lectures as sociology, psychology and history philosophy comprehensively particularly at the undergraduate level as such courses will help them make sense of humans, communities and events. Such an approach will enable both teacher candidates and their prospective students to interpret the conditions of the periods during which the events occured on the basis of cause-effect, actor, act and factor dimensions instead of just memorizing the past events.

In conclusion, it must be stated that each of the problems in history teaching is directly related to one another. Therefore, it may be asserted that it will useful to look at the problems with a holistic approach instead of addressing the related issues individually. Otherwise, a problem that is partially solved may cause another problem to persist or even lead to different problems. At this stage, just as 2023 and 2071 targets of the state are expressed and arrangements are made in accordance with these targets, a series of national policies and practices in the field of education needs to be implemented in a planned manner. Instead of 
changing curriculums as the ministeries of educaton change, there exists a need for a sound educational policy focusing on achieving the country's future goals is urgently needed in the field of history teaching, as is the case in all areas of education.

\section{Referances}

Akter, A. (1999-2000). Anılar bibliyografyası [Memoirs bibliography]. Çağdaş Türkiye Tarihi Araştırmaları Dergisi, 3(9-10), pp. 229-265.

Altıkulaç, A. \& Gökkaya, K. (2014). Tarih öğretiminde hatıratların kullanımının tarihsel empati becerisine etkisi. Turkish Studies, International Periodical for the Languages, Literature and History of Turkish or Turkic, 9(1), pp. 21-35.

Aslan, E. (2006). Neden tarih öğretiyoruz? [Why do we teach history?], Dokuz Eylül Üniversitesi Buca Eğitim Fakültesi Dergisi, 20, pp. 162-174.

Birinci, A. (1998). Hatırat türünden kaynakların tarihi araştırmalardaki yeri ve değeri [The place and value of sources of memoirs in historical research]. Atatürk Araştırma Merkezi Dergisi, Prof. Dr. Fahir Armaoğlu Özel Sayısı, XIV(41), pp. 611-620.

Demircioğlu, í. H. (2006). Avrupa birliği ülkeleri ve Türkiye'de tarih öğretiminin genel amaçlarının karşılaştırmalı bir değerlendirmesi [Comparison and Evaluation of General Aims of The Teaching of History Between Turkey and European Union's Countries]. Fırat Üniversitesi Sosyal Bilimler Dergisi, 16(2), pp. 133-146.

Demircioğlu, i. H. (2014). Tarih öğretimi, öğretim teknolojileri ve materyal tasarımı [History education, instructional technologies and material design], Tarih Öğretiminde Öğretim Teknolojileri ve Materyal Tasarımı [Instructional technologies and material design in history education]. (Second Edition), (Editors: İsmail H. Demircioğlu \& Ibrahim Turan), in: 1-12, Ankara: Pegem.

Deveci, H. (2007). Teachers' views on teaching current events in social studies. Educational Sciences: Theory \& Practice, 7(1), pp. 446-451.

Dönmez, C. \& Tangülü, Z. (2012). Türkiye Cumhuriyeti İnkılap Tarihi ve Atatürkçülük Dersi'nde öğretmenlerin gazete kullanımına ilişkin tutumlarının çeşitli değişkenlere göre 
incelenmesi [Investigating Turkish republic revolution history and kemalism teacher attitude toward using newspaper in the class in term of some variable]. Gazi Üniversitesi, Gazi Eğitim Fakültesi Dergisi (GEFAD), 32(2), pp. 347-361.

Dönmez, C. \& Yazıcı, K. (2013). Türkiye Cumhuriyeti İnkılap Tarihi ve Atatürkçülük ders kitaplarında tarihi karakterlerin kullanımını etkileyen faktörler [Factors Affecting the Use of Historical Characters in Republic of Turkey Revolution History and Kemalism Textbooks]. Ahi Evran Üniversitesi Kırşehir Eğitim Fakültesi Dergisi (KEFAD), 14(3), pp. 243-265.

Dönmez, C., Yazıcı, K. \& Uslu, S. (2015). Tarih öğretmenlerine göre hatıratların eğitim -öğretim sürecinde kullanılabilirlik durumları [According to history teachers, the use of memories in educational process]. Trakya Üniversitesi Sosyal Bilimler Dergisi, 17(1), pp. $255-270$.

Gedik, H. (2010). Güncel olayların ilköğretim sosyal bilgiler derslerinde kullanımı ve öğrenci görüşleri [Using Current Events in Elementary Social Studies Courses and the Views of Students]. Ahi Evran Üniversitesi Eğitim Fakültesi Dergisi, 11(2), pp. 97-118.

Hanilçe, M. (2008). II. Meşrutiyet dönemine dair hatırat bibliyografyası denemesi [An Essay on the Bibliography of Memoirs on The Second Constitutional Era]. Bilig, (47), pp. 147166.

Kabapınar, Y. (2009). Öğretmen Adaylarının Kronoloji Becerilerinin Saptanmasına Yönelik Bir Çalışma [A Study on determination of chronology skills of prospective teachers]. IV. Sosyal Bilimler Eğitimi Kongresi, (7-9 Ekim), İstanbul, Marmara Üniversitesi.

Kaya, R. \& Demirel, M. (2008). Lise 3. sınıf öğrencilerinin tarih derslerindeki ilgi alanları (Erzurum Örneği) [Areas of interest of high school 3rd grade students in history courses (Erzurum Case)]. Atatürk Üniversitesi Sosyal Bilimler Enstitüsü Dergisi, 11(1), pp. 163177.

Kaya, R. \& Güven, A. (2012). İlköğretim yedinci sınıf öğrencilerinin sosyal bilgiler derslerinde tarih konularının işlenişi ve tarihin değeri ile ilgili görüşleri [Opinions of primary education seventh grade students about teaching of history topics in social sciences 
and significance of history], Turkish Studies- International Periodical For The Languages, Literature and History of Turkish or Turkic, 7(2), pp. 675-691.

Köse, M. \& Yıldız, A. (2012). Tarih eğitiminde sosyal ve kültürel konuların öğretimi [Teaching of social and cultural issues in history education]. Sosyal Bilimler Araştırmaları Dergisi, I, pp. 81-99.

Kuzgun, M. \& İncili, Ö. F. (2016). Sosyal bilgiler öğretmen adaylarının tarih derslerinin işlenişine yönelik görüşleri (Kilis örneği) [View of Social Studies Pre-Service Teachers on Teaching History Courses (Kilis Sample)]. Sosyal Bilimler Dergisi, 6(11), pp. 158-175.

Lilletun, J. (2003). "Okulda Tarihin Rolü: Bir Norveç Perspektifi" [The Role of history in school:

A Norwegian perspective], Tarihin Kötüye Kullanımı [Abuse of history], (Çeviren: Nurettin Elhüseyni), Türkiye Ekonomik ve Toplumsal Tarih Vakfı Yayını, (Tarihin Kötüye Kullanma Biçimleriyle Yüzleşmek Sempozyumu, Oslo, Norveç/ 28/30 Haziran 1999), pp. 112-117.

MEB [Minisrty of Education]. (2017a). T.C. İnkılap Tarihi ve Atatürkçülük Ders Programı (Ortaokul 8. Sınıf) [Turkish Republic Revolution history and kemalism course curriculum $\begin{array}{lllll}\text { (Secondary school } & \text { grade }], & \text { Retrieved from }\end{array}$ http://mufredat.meb.gov.tr/ProgramDetay.aspx?PID=193, on 20.10.2017.

MEB [Minisrty of Education]. (2017b). Ortaöğretim T.C. İnkılap Tarihi ve Atatürkçülük Dersi Öğretim Programı [Secondary School Turkish Republic Revolution history and $\begin{array}{llll}\text { kemalism course } & \text { curriculum], } & \text { Retrieved }\end{array}$ http://mufredat.meb.gov.tr/ProgramDetay.aspx?PID=167, on 20.10.2017.

Memişoğlu, H. \& Güçin, G. (2017). Sosyal bilgiler öğretmenlerinin görüşlerine göre güncel konuların öğretimi [Current issues teaching according to the opinions of social studies teachers]. International Journal of Social Sciences and Education Research, 3(4), pp. 1274-1295.

Oktay, A. \& Unutkan Polat, Ö. (2005). Okul öncesi eğitimde güncel konular [Current issues in pre-school education], İstanbul: Yaylacık.

Özen, İ. (2017). Hatıratın hikâye ve roman türüyle ilişkisi [The Relation of memoirs with story and novel], Türklük Bilimi Araştırmaları (TÜBAR), XLI, pp. 233-256. 
Öztürk, M. K. (2002). Liselerde coğrafya öğretiminde araç, gereç, materyal kullanımı ve önemi [The Importence and usage of educational technology devices and materials in geography teaching in high schools]. Hacettepe Üniversitesi Eğitim Fakültesi Dergisi, 22, pp. 126-129.

Safran, M. (2006). "Türk tarihi öğretimi ve meseleleri" [Turkish history education and its issues], Tarih eğitimi makale ve bildiriler [In, History education articles and proceedings], pp. 175-189, Ankara: Gazi Kitabevi.

Stradling, R. (2003). 20. Yüzyıl Avrupa tarihi nasıl öğretilmeli [How should 20th century european history be taught]. (Çeviren: Ayfer Ünal), İstanbul: Türkiye Ekonomik ve Toplumsal Tarih Vakfı.

Şengül Bircan, T. \& Safran, M. (2013). Tarih öğretiminde haritaların önemi ve kullanımı [The Usage and the importance of maps in teaching history], Ahi Evran Üniversitesi Kırşehir Eğitim Fakültesi Dergisi (KEFAD), 14(2), pp. 461-476.

TDK “Türk Dil Kurumu” (2017). "Şans” [Luck], "Kader” [Fate]. Retrieved from Updated Turkish Dictionary in http://www.tdk.gov.tr/ on 07.08.2017.

Ulusoy, K. (2009). Lise öğrencilerinin tarih dersinin işlenişi ile ilgili düşünceleri (Ankara Örneği) [High School Students' Views About Instruction of History Lessons (A Case Study in Ankara)]. Ç.Ü. Sosyal Bilimler Enstitüsü Dergisi, 18(1), pp. 417-434.

Yazıcı, K. \& Özdemir, G. (2016). Ders kitaplarında tarih konularının öğretiminde kullanılan haritaların temel özelliklerinin incelenmesi [The Investigation of the basic features of maps used in teaching history subject in course books], Mehmet Akif Ersoy Üniversitesi Eğitim Fakültesi Dergisi, 40, 506-520.

Yılmaz, K. \& Koca, F. (2012). Tarihsel empati üzerine nitel bir araştırma: Tarih öğretmenlerinin algı, görüş ve deneyimlerinin incelenmesi [A Qualitative study on historical empathy: examination of history teachers' perceptions, perspectives and experiences]. Gaziantep Üniversitesi Sosyal Bilimler Dergisi, 11(3), pp. 855-879. 